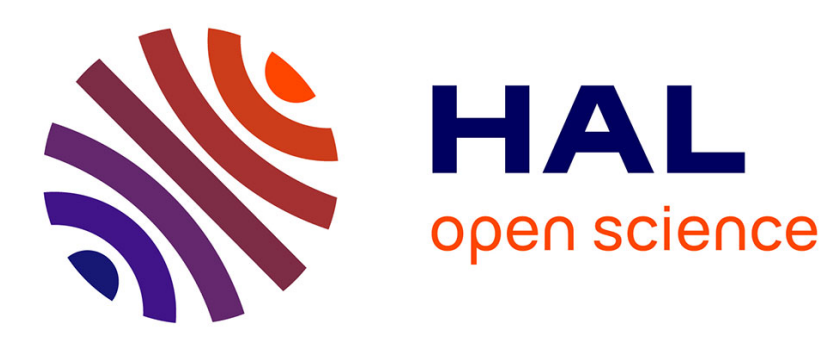

\title{
Sensorial discourse and corpus in the digital humanities era: The example of the wine language
}

Matthieu Bach

\section{To cite this version:}

Matthieu Bach. Sensorial discourse and corpus in the digital humanities era: The example of the wine language. Digital Scholarship in the Humanities, 2019. hal-02011281

\section{HAL Id: hal-02011281 \\ https://hal.science/hal-02011281}

Submitted on 8 Feb 2019

HAL is a multi-disciplinary open access archive for the deposit and dissemination of scientific research documents, whether they are published or not. The documents may come from teaching and research institutions in France or abroad, or from public or private research centers.
L'archive ouverte pluridisciplinaire HAL, est destinée au dépôt et à la diffusion de documents scientifiques de niveau recherche, publiés ou non, émanant des établissements d'enseignement et de recherche français ou étrangers, des laboratoires publics ou privés. 


\title{
Sensorial discourse and corpus in the digital humanities era: The example of the wine language
}

\author{
Matthieu BACH
}

Université Bourgogne Franche-Comté - EA 4182

This article intends to define sensorial discourses, to discuss the way they should be analyzed by stressing the importance of corpora. Putting these thoughts into the context of the digital revolution, it will show how corpora should evolve in the digital humanities. The association of digital and sensorial discourses needs to be clarified and this paper proposes a way to find new approaches to better analyze them.

Keywords: Multimodal Corpora, LSP, Sensorial studies, Digital Humanities

\section{Research question and objectives ${ }^{1}$}

The goal of this contribution is not to answer a question nor to bring anything new to the table, but rather to argue for a new structuration of sensorial speech objects analysis and to find new paths in the digital era.

Speaking about feelings, emotions, senses, experiences introduces a wide range of highly cognitive components in a language. The production of such components is unconscious, but remains a challenge for linguists. We conclude that it is possible to access senses through language; it simply requires a strong methodology and an effective corpus compilation.

This paper thus seeks to introduce a new branch of linguistics with the sensorial studies and especially the sensorial discourses. Since the definition of this concept is closely related to corpus and to the digital humanities, the second part of this contribution will introduce the corpus in the digital era. Presenting the problems in combining both sensorial 
and digital discourses, the final part of this paper will lay out a vision of what could be a possible approach for both elements.

\section{What are sensorial discourses?}

After the linguistic (Rorty, 1967), the pragmatic (Bernstein, 2010), the pictorial (Mitchell, 1994), the cognitive (Gardner, 1985) and the cultural (Jacobs \& Spillman, 2005) turn, we would like to introduce the sensoric turn (see also Digonnet, 2018). Each of these revolutions have changed the way the human sciences have done research. The digitalization of techniques and exchanges is creating a new worldwide economy and society (see section 2.1), a part of it is carried through a sensorization of the global discourse. This first part of the article will thus be dedicated to an attempt at defining sensorial discourses, which links its two mains "pillars": emotions and experience.

\subsection{Sensorial discourses: a definition}

From the proposition of Busse \& Teubert (1994) as a virtual corpus, shared by a limited community, making the link between texts which are produced by this community and the cognitive representation of each member of the community, it seems interesting to introduce the work of Fairclough (2005), based on Fairclough \& Wodak (1993), which underlies the social characteristics of discourses: they are objects which simultaneously shape and are being shaped by the social element. This should be completed French discourse theories with Longhi (2009, p. 80) and his phenomenological (sensu Merleau-Ponty, 1969) approach

associated to senses perceptions, created by the textual progression dynamics ${ }^{2}$. The main idea is the circularity and the completude of textual meaning: phrases (or semantic propositions) being at the same time the base and the extension of the previous and the following ones. On this idea, Wagener (2016) develops a more pragmatic and plurisemiotic approach arguing that discourses are not only composed by basic semiotic units, but also made by all the extralinguistics elements constitutive of the discursive activity (socio-economic environment, societal reality, history etc.). Discourses can then be defined as dynamic cognitive molecules, composed of plurisemiotic atoms, conceptually linking an individual, a specific community 
and a social reality. Discourses are so the result as well as he foundation of a moving social interaction.

It is also to stress that sensory discourses are specialized discourses and in this matter $a$ specialized discourse does not exist, there can only be specialized discourses. Petit (2005) shows that specialized discourses are built against specialized fields with their respective social environments and their cultural and historical background.

Essentially, sensorial-based texts (text is used here in its broad sense) are speech productions relying on senses, in their popular understanding: sight, hearing, touch, smell, and taste. The specificity of such production is their high potential for semantic analyses because of the lack of lexicon proposed by Indo-European languages (Majid \& Burenhult, 2014). So, if any French, German or Spanish person would like to express complexed aromas, visualization or sounds, they will have to use basic words and to modify their meanings with other basic words like modulators (a lot, many, a few etc.) (see San Roque et al., 2018 for interesting studies of the polysemy of perceptions verbs). In recent research on wine language, it has been shown that terminology is essentially based on comparison with other items, with other previously tasted wine, with prototype (sensu Rosch, 1973, 1975) and with modulation to adjust the term to the wills of the speaker (Bach, 2017a; Gautier \& Bach, 2017). The presence of enunciation tags, such as "in the nose" or "in mouth" also enables the speaker to use one descriptor or one flavor for different senses.

A first link between language and sensoriality can be found by using large set of data, meaning corpora. One possibility is to observe constructions (sensu Goldberg, 1995, 2006) in discourse. The following examples are from Gautier \& Bach, 2019:

(1a) donc là on est vraiment sur [le fruit croquant] en plus

(1b) und das ist [ganz ganz leichte intensive Weine]

Sensorial elements like "fruit croquant" or "leicht intensiv" are here encapsulated in stabilized form-meaning-structures, which can be discovered by using corpora (Gilquin, 2010; Gries \& Slocum, 2017).

It needs to be underlined that this is not an automatic extraction from meaning, but a computer-based approach (identifying repeated morpho-syntactical structures) with a human analysis (the researcher identifies the evaluative components of the structures). Römer (2008, 
p. 116) points out the difficulty of automatic extractions of evaluative elements in political discourses. Sensorial-based speech production is sui generis evaluative. This evaluation has however different facets (Gautier, 2018).

Sensorial studies reject an analytical approach of dividing each sense, favoring a global multisensorial perspective (Dubois, 2009a, p. 7), which combines linguistics, psychology, cognitive sciences, and specialized knowledge. It is based on pure and applied research in each field so that specific domains-studies can evolve. The essence of sensorial studies is then holistic and targets every layer of the language: terminology, syntax, discourse, cognition. This then implies the use of corpus in an objectivist way (in order to reach a scientific truth through the concept of falsifiability of results Popper, 1999, Dubois, 2009b, p. 15) leading to a situated approach (Condamines \& Narcy-Combes, 2015) of the applied linguistics (Candel, 2011), meaning that this linguistics is not only empirical but also theoretical. This applied linguistics is a non-exclusive linguistics, which tends to integrate works of e.g. communication or marketing studies, consequently giving a broader sense of understanding the language as a multimodal complex (Defossez \& Boutaud, 2013). The cultural $^{3}$ part of the language and of the sensorics ${ }^{4}$ must be taken into consideration through in our vision - a cognitive point of view (Sharifian, e.g. 2017).

Finally, sensorial studies are not strictly oriented to each individual faculty. Senses do not work on their own (Guastavino, 2009) and one sense does not exclude another, they work together to offer a global sensorial perception (Ascone et al., 2016 shows the role of the visual in the oral perception):

(2) alors là euh bon a euh un arôme goût miel donc un petit peu comme ça fort en bouche et et quoi fort au nez surtout pour l'instant euh fort au nez c'est le goût de miel qui apparaît et puis après dans le fond on a l'arôme fleur blanche euh fleur d'acacias / voilà (FR_VG_IL_01)

Language and sensoriality are extremely linked, this is the well-recognized fact, what is not however acknowledged is the nature of the $\operatorname{link}(\mathrm{s})$. The most promising way is to consider the sensoriality as multifactorial (essentially based on experience which is it-self multimodal per se, see below) and to include it in cognitive structures like frames (Fillmore, 1985) (see also Faber \& África Vidal Claramonte, 2017). Sensorial reception is then combined to other integrated cognitive complexes such as emotions and experience. 


\subsection{Links with emotion and experience $e^{5}$}

Speaking about a sensorial product like wine does not only involve describing the wine in front of the speaker, it also requires expressing emotions, and remembering other tastings and visits in vineyards or in fresh markets while e.g. smelling fresh vegetables.

Even if it is not yet clear what emotions really are (Schwarz-Friesel, 2013, pp. 43-48), they are everywhere around us, whether we're speaking with our friends, going to the bar or watching a movie, etc. Emotions can be defined as high cognitive units based on conceptualizations of moments (Boutaud, 2007) that are composed of different kinds of information (mimic and facial expressions (Ekman, 2010), visualization, sounds, touch (Goldstein et al., 2018), odors etc.) retained in long-term memory (cf. Richins, 1997, p. 127; Ledoux \& Hofmann, 2018, p. 69). Having an emotion is extracting a sequence of the emotional present situation, actualizing a sequence of information stored in the memory and making them match. The result of this matching process is the emotion.

So, while walking in the street, someone smells a specific odor and smiles because it reminds them of a memory of the smell of their girlfriend/boyfriend. The memory refers not to a specific memory but to an association of the smell with a cognitive construct, which brings, in this case, happiness (see also Damasio, 2018).

If the same person gets not an emotion through the memory process, but rather a "real" memory (Gordon, 1986; Ricœur, 2006), which means a cognitive pictorial visualization of a previous event, then this is the memory of a past experience. Emotion can then be included in experience. ${ }^{6}$ The experience has a deep cognitive construct which can be explained by its links with working memory, inner speech or mental images (Baars, 2005, p. 49). It is primarily physical, it has to be lived, experienced to be memorized and attached to feelings, emotions and visualizations. The process of memorizing is nonetheless selective because we only have access to instants of the sequence.

Vandeloise (1991) underlined that language does not reflect the world but rather the experience. In other words, we do not translate what really happens, but what we have (unconsciously, selectively) memorized. Experience marketing "plays" on this statement to create a warm atmosphere of desire that the client will remember and which will push her/him to buy (see Daucé \& Rieunier, 2002; Vernet \& Rieunier, 2004). 
For linguistics and discourse analysis, the propositions of Auchlin and his colleagues make sense to get an inclusive view of a speech reality at a given time point:

En résumé, on dira qu'adopter une approche praxéologique et expérientielle du discours revient à considérer les actions et les activités avec lesquelles elles sont en lien comme les catégories centrales d'une étude des situations ou des contextes de production du discours. Plus spécifiquement, elle consiste à admettre que l'expérienciation des situations d'action par les agents procède nécessairement d'un double façonnage : a) un façonnage par l'activité, qui préforme les significations par leur indexation socio-historique, b) un façonnage par le discours luimême, dont l'expérienciation permet aux interactants de co-construire localement des représentations intersubjectives de la situation d'action. (Auchlin et al., 2004, p. 226)

The pragmatic aspect of the view is to underline. What humans do and say is essentially based on past (shared) experiences of a community. This brings the problem of the transposition of concepts into words and their references (Mondada \& Dubois, 1995; Resche-Rigon, 2009). A possible answer to this problematic would be to consider the meaning as the association of a semantic meaning (to be brief: the dictionaries definitions) and a pragmatic meaning (the meaning of a word or expression in the enunciation context, see Wittgenstein). We should also follow a cognitive approach like the one developed by Lakoff (1987) and in the four criteria of Geeraerts (2006). We wish adapt this approach to sensorial discourses by adding the notion of emotion, which definitely is of consequence when considering the three components described here.

\section{Corpus in the digital humanities}

A linguistics study, regardless of the subject, cannot argue to be realistic without a corpus analysis, whether as a starter, or as a way to validate a theory. Corpora have been exploited since the birth of dictionaries until now, and will have to evolve as we enter a new era, the one of the digital humanities.

\subsection{Digital Humanities: a new era for linguistics}

When electronics have switched from an assistance to human works and activities to a replacement of the human in these activities, the world will have known another revolution: the 4.0 Industry $^{7}$ (Brühl, 2015). This new era in the economic and social world is being 
provoked by the appearance of artificial intelligence and the growing ability of computer and robots (Ang et al., 2016) which are enabling a reduction of cost production in the industry branch, a better use of resources and a more client-oriented strategy - the so-called personalization (Wang et al., 2017). ${ }^{8}$ All of that is only possible thanks to a mass data collection:

i. The more data two robots or a sensor and robot can exchange, the more they will learn and in fine the more efficient they will be (Kolberg \& Zühlke, 2015);

ii. The more data a company can get from its clients, the more precisely it can target their desires (Bauernhansl, 2017, p. 9);

iii. Etc.

Another way to understand this, is to see these exchanges of data as a network (Schlick et al., 2013). The interconnection can be restricted; for instance, some robots in a smart factory which communicate together to adjust the production in real time and with the human staff to resolve problems ${ }^{9}$ or take orders, and within the human staff: from the worker to the teamleader and to other departments. ${ }^{10}$ It is also conceivable that in a few years, customers will only buy from home and receive their products without moving from their houses (Mindas \& Bednar, 2016, p. 25). So, they will interact with sellers to find what they really need and how they want it.

The BMW future vision ${ }^{11}$ shows what an extended communication is. The car will be connected to a smart watch and to other smart devices in the house in order to interact with its driver/user. Once the driver has "told" the selected car (if the user owns more than one car) to come to her/him, (s)he will enter a car fully connected to her/his other devices. The car will communicate the navigation details once the driver has entered the destination into the GPS. When the road becomes difficult, the human driver drives. When it becomes easier the autopilot takes the lead, so the driver becomes a user and can do other things like reading her/his emails from the information device of the car, organizing a videoconference, and so on. If the car detects a crash of another car leading to a general slowdown of the traffic, it communicates the information to other cars. The car does likewise if it finds a dangerous object (like a rock on the street). When it arrives in town, the car will drop the driver/user where (s)he wants to go and park itself in a connected parking lot, waiting for the user to "call" it again. ${ }^{12}$ 
This new era is also an opportunity for human sciences to evolve to a new art: digital humanities ${ }^{13}$. Even if this new field is still embryonic because it brings up a certain number of epistemological questions, it opens up new research paradigms and teachings:

The digital humanities comprise the study of what happens at the intersection of computing tools with cultural artefacts of all kinds. [...]. It probes how these common tools may be used to make new knowledge from our cultural inheritance and from the contemporary world. [...] It teaches students to use computing as an instrument to investigate how we know what we know, hence to strengthen and extend our knowledge of the world past and present. (Center for Computing in the Humanities, quoted by Svenson, 2010, §31)

To be brief, digital humanities in its wider definition, is a new way of thinking and achieving research by combining digital tools and data with regular theories and data. ${ }^{14}$ It has been created to follow the evolution of humanity regarding the increasing integration of digital elements. Digital humanities are based on research carried out until now to expand them through an interdisciplinary process ( $c f$. infra).

As linguists, these exchanges of information will bring a new range of material (Berry, 2012, p. 2), redefining the way we interact and talk to other human and non-human beings. In fact, language in its broader conception is the key element of any network. To analyze these elements, linguists will have to collect data in the shape of a corpus. Since 1960 and the Brown Corpus ( $c f$. Svartvik, 2007, p. 14), corpus is a prerequisite to most linguistic analysis (Tognini-Bonelli, 2001). Indeed, corpus allow researchers to have a look at the language reality and not to rely on their feelings (Fillmore, 1992, p. 35; Lemnitzer \& Zinsmeister, 2015, p. 11$)^{15}$.

Looking at the language through corpora is actually looking at usage-based meaning (These 1 of Teubert, 2005). We have emphasized usage-based because it is exactly the purpose of using corpora. These data sets allow linguists to access the reality of the language as it is used. For wine discourse, it helps researcher to reveal the specialized meaning of some expressions. For the sake of discussion, let us take the term "terroir" which is originally coming from French. The notion of terroir is unstabilized, even if definition has been proposed and one accepted as the definition when using in wine texts (see Flutet 2015, pp. 192-193). Using corpora will help to define the term as it is actually used by some population and not by academics and so-called experts, and to contrast usage in French and other languages. 


\subsection{New corpora, new object of studies}

A first step has been made with the production of so-called giga corpora (the first of them is the well-known British National Corpus (BNC) presented in Leech, 1992) to deeply explore language. ${ }^{16}$ We argue that for Language for Specific Purposes ${ }^{17}$ (LSP)-studies such enormous sets of data are not useful. They can open reflections but they cannot bring answers. No distinction can be made between natural language and LSP (Charnock, 1999), the only difference can be found in the frequency of elements, which can be higher in LSP, or in specific lexical relations (collocations, e.g. Sfar, 2013). So, if one LSP is a virtual selected space in a natural language (see Fig. 1), smaller corpora can be used.

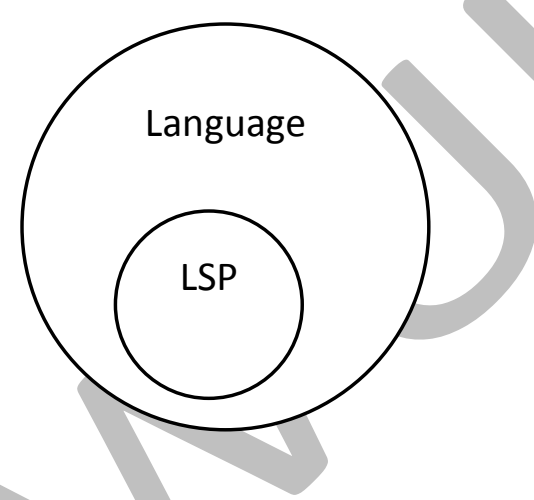

Fig. 1: LSP-Language Visualization

Until now, corpora have been made of texts which follow mainly the one-to-one or one-to-many communication structure. As seen in the previous section, this will change and include new structures such as one-to-one, where one or both speakers could be an AIspeaker, many-to-one (all the robots of a factory to one human controller):

i. Between robots in a factory or in experiments like a "discussion" between two smartphones, it will be interesting to observe how they exchange and in case of an issue, how they intend to resolve it and how they actually resolve the issue;

ii. Between a robot and a human: when a consumer asks a chatbot on an onlinecommercial website (an example of a chatbot on social media is proposed in $\mathrm{Xu}$ et al., 2017 and below with "Margot the wine bot" from Lidl.uk);

iii. Between humans through interfaces (which is already possible with digital social media). 


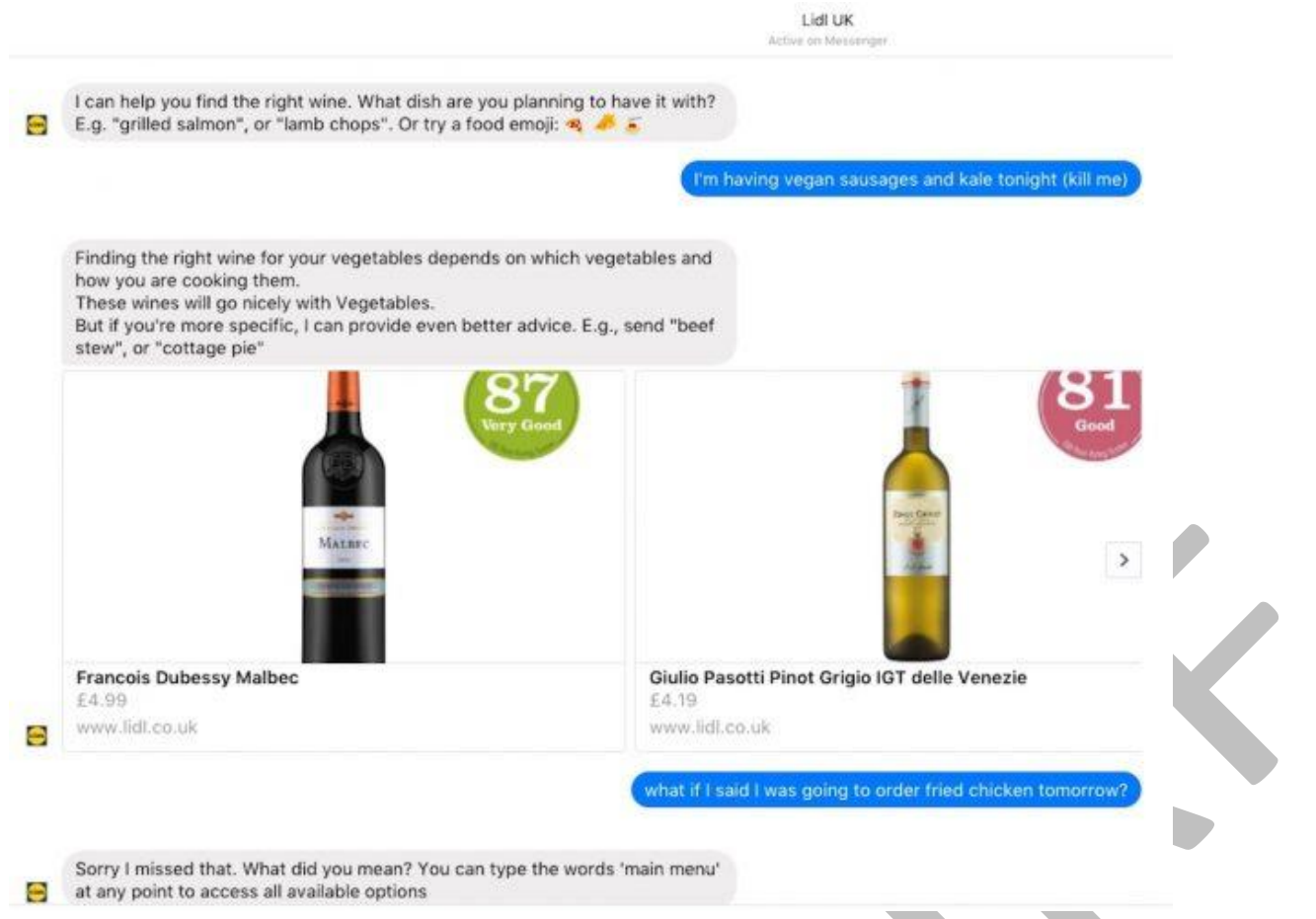

Fig. 2: Example of a conversation with a chatbot (source:

https://www.thedrinksbusiness.com/2018/01/lidl-has-a-new-facebook-tool-which-helps-youpair-wines-with-food-heres-how-it-works/)

This means, therefore, the possibility of a new range of corpora which could already exist in their "prehistorical" forms. Below are some examples:

i. Instagram-/Pinterest-corpora are interesting because they put picture before text, signaling that the text is subordinate to the picture not like in a newspaper article, where the picture illustrates the text;

ii. Booktype-corpora would be a collection of novels, which have been collaboratively written. Thus, data are composed of the novel itself, the textual exchanges and comments between the writers during the writing-process and the comments of the readers;

iii. Strava ${ }^{18}$-corpora allows data sets composed of textual data (comments of the activity) with possibly pictures, geographical data (the GPS track record) and physiological data (power or heart rate) (for an example with Tweets and geographical data see Barbaresi, 2016). 


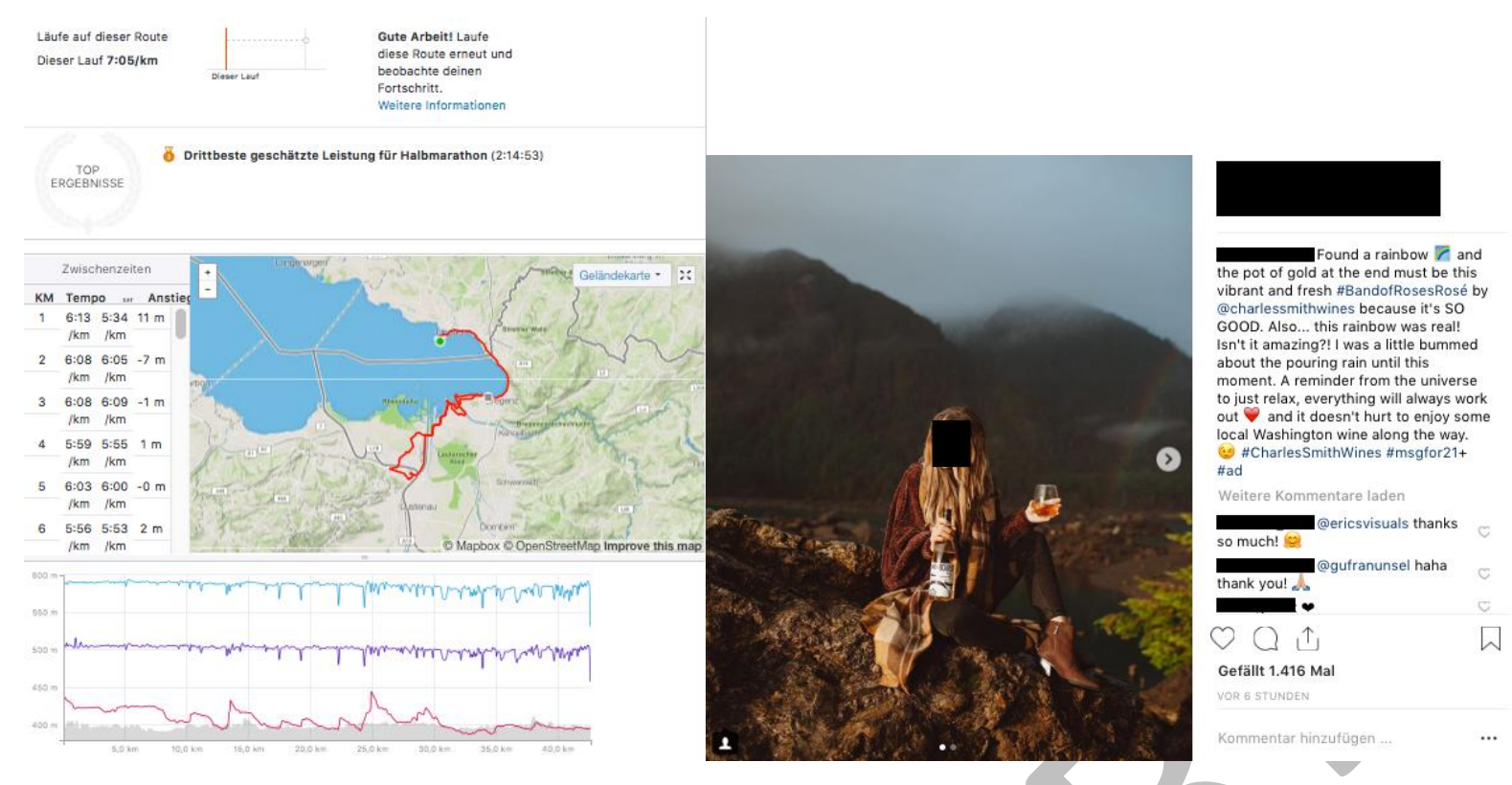

Fig. 3: Example of Strava-Activity (left) and Instagram-Post (right)

However, we would like to stress the fact that a heavy corpus linguistics, which is a corpusdriven linguistics with the use of specialized software, would not be the best way to analyze LSPs. As suggested before, LSP-studies need only small corpora; thus, manual analyses combined to light software like TXM (Heiden, 2010) seem to be a more efficient way to access the core of the speech product. This would take the name of a linguistics of corpus (Mukherjee, 2010).

A linguistics of corpus is a bottom-up-top-down approach which first collects data sets according to a global problematic, watches them refine this problematic, and targets appropriate theory backgrounds. This corpus-driven stage is then followed by a corpus-based part, where the analysis made according to the selected theories are controlled by comparison with the corpus. It has to be underlined that this methodology is human based and do not let the key of the analysis to computers and software, even if it uses some of them.

\subsection{A multimodal and interdisciplinary approach}

So, in the same way economics and industry have moved from a systemic use of electronics to the implementation of digital technologies for themselves in new paradigms, it can be argued that linguistics should also take this turn. 
Until now, linguistics has always been a science regarding the past because it has needed to identify, collect and analyze data, with the consequence that linguistics' results did not have impacts on speech reality. The digital era allows researchers to work faster and to make direct contact with the language. To do so, linguists have to change the way they view their job and try to work in a more interdisciplinary ${ }^{19}$ and multimodal way.

Interdisciplinarity is essential for LSP-linguists because they cannot be specialists of linguistics and of the specialty itself. It is better if they know some elements but also need the help of specialists. In wine, to really understand what is said and to be able to analyze it, knowledge in pedology, ampelography, law, etc. is needed. This also allows linguists to go beyond terminology issues and investigate preferential semantic association, polylexicality (see Greciano, 1995) and then phraseology, which leads step by step to different kinds of patterns (Gautier, 2014, 2017).

Multimodality is becoming a necessity when global meaning needs to be studied. Text is not the only way to express oneself; indeed, making a drawing or taking a photo and posting it on Instagram is significant as well as the design of the document itself (Schriver, 1997, p. 10). The connection of this data makes sense. That is why it is more than relevant to consider the connection of these elements as support of the meaning (Bucher, 2007, 2010; Kress \& van Leuwen, 2001). We would also follow the proposition of Mondada (2018, p. 3) and rather speaking of multisensoriality ${ }^{20}$, because "[p]articipants do not only gesture, arrange their bodies and move in visibly intelligible ways to communicate, but they also use their bodies to feel the environment and use multimodal resources to express, manifest and display their sensory access to the world."

Two short examples illustrate in which direction, according to this vision, sensorial discourse linguistics should go.

The paper of Andréys et al. (2018) is a good example for communication studies on online language. The paper analyses websites of online wine sellers (Online Pure Player only) in Germany. The specificities of wine allow it to be sold online because it is not stricto sensu an experiential product, as the authors underline it, quoting Stenger (2004) from the introduction. The study relies on Marketing- and Cultural Studies-theories. It shows with statistical interpretations how the websites are build and which elements compose them. This paper is completed by the work of Bach (forthcoming), which analyzes wine notes from the same economic players in Germany and in France. The underlying idea is to compare both 
discourses by using one comparable and one parallel corpus. The analysis shows that culture, emotion, experience and senses are deep structures of the wine language through a deep study of pragma-semantic patterns.

However, we need to bear in mind that not all corpora can be produced through the Internet.

\subsection{What Internet cannot (yet) bring}

While the promises are considerable, digital corpus cannot yet bring everything. It is a legal issue rather than a technical one, even if linguists need to have strong IT-knowledge in order to build an efficient data-collection-platform.

It is then not feasible to create a corpus from Instagram. Even if attempts have been made (Bach, 2017b; Thimm \& Nehls, 2017), it is acknowledged that Instagram's API, based on that of its owner, Facebook, does not allow an automatic wide data collection process:

4. You cannot use the API Platform to crawl or store users' media without their express consent.

5. Do not abuse the API Platform, automate requests, or encourage unauthentic behavior. This will get your access turned off. (Instagram)

What is possible is a random manual collection, with the issue of asking people to use their publications.

Youtube is also a sensitive subject: it offers a large set of free data but they are still subject to copyrights, which means that the researcher has to ask the video producer and the speaker in order to use the video. If people are seen on the video, the researcher has to ask them as well.

For the moment, and to our knowledge, only Twitter allows the compilation of huge and reliable data sets (e.g. Dang-Ahn et al., i. a. 2013; Longhi, 2016, 2018; Longhi et al., 2017; Paveau, 2013a, 2013b; Thimm et al., i. a. 2012, 2017; Fen-Chong, 2017; Spina, 2017). All these works show the enormous possibilities of new speech productions and new challenges for linguists.

Other issues appear with the widespread use and versatility of techno-discursive tools such as \#, @ or RT: 
i. If you are French and want to collect data on wine, you can collect all publications with \#vin, but also encounter the following problem:

(1) Vin = wine;

(2) Vin = friends in Finnish;

(3) Vin $=$ the actor Vin Diesel.

This means that corpora must be carefully prepared (by preparing metadata and selecting exclusive criteria) and that human intervention still plays an important role;

ii. If one is interested in collecting publications about the French region of Jura by using \#jura or only by word detection "jura", one might find what one is looking for, but in the data set, there will also be a certain amount of publications about wine (the region is a AOC-wine appellation) and from students; because, Jura means Law Studies in German.

Both examples show that the outside simplicity of digital data tends to make data collects more complex as collects of regular data, like textbooks and oral corpora.

\section{Applying corpus to sensorial discourses in digital humanities}

After having defined sensorial discourses and reviewing key elements of corpora, the third section of this paper offers a vision to combine both of them and observe what one can bring to the other.

\subsection{The limits of the digital language}

The collusion of sensorial discourses and digital language offers a big challenge for text producers: how will they transmit a sensorial message through an impersonal object? The question of the synchronicity of the interaction is also important: the client speaks with a chatbot about buying - for instance - a wine bottle, (s)he does not have to buy it after the discussion, (s)he can also wait for a few hours or days during the discussion. The effects of 
the interaction time dilatation will impact the way the seller sells products, especially sensebased products. An important part of the selling process for wine is based on storytelling (Lamarre, 2018) about the wine-making process and the winemaker's history (Bach, 2017a), playing with emotive responsiveness of the clients; if the seller cannot activate this part or if clients break the emotional bond between them and the seller, the sale is more likely to be unsuccessful. At the same time, recent research has shown that analogical emotions and emotion contagion can be transferred into the virtual world (He et al., 2016).

Interestingly enough a computer-mediated interaction can also bring more naturalness and distance because the computer and the non-presence of the other actant can have disinhibiting properties (McKenna \& Bargh, 1999). Nonetheless, the lack of diversity in expression brings important restraints in producing and receiving emotions: mainly textual information is exchanged and facial expressions or gestures are not, and they both are particularly important in human interactions (Ekman, 2010). ${ }^{21}$

Digital interactions are not particularly effective for emotionally based discourses and interactions, which will require new approaches and theories in communication, marketing and semantics fields, but also in IT fields. Here, an interdisciplinary work is more than necessary.

The notion of an expert is also evolving. Until recently, an expert was someone who had the knowledge of something and wanted to convey it to other people. Experts are nowadays present in our daily lives, particularly in the media. In the evening news, economics experts follow social experts and political experts. Morange (2009) underlines the multiplicity of appellations throughout disciplines. She distinguishes two kinds of function: the social function (the expert has skills) and the cognitive function (the expert has knowledge) (2009, p. 153). It is possible that in the next few years this dichotomy will evolve. With the Internet, an expert is someone who has a large audience, which means someone who is able to market her or himself. ${ }^{22}$ An expert can now be anyone. Influencers are often considered experts in their fields by their followers, which could vastly change the interaction between expert and non-expert (see also Flichy, 2010, Chap. 1).

Indeed, Valentin et al. (2003) show that a wine expert is someone who is well enough trained to be able to successfully recognize wine flavors and aromas and to distinguish wines. This way of considering experts shows that wine experts are not only sommeliers, who have competences, or professors (who have certified knowledge), but also wine amateurs, who have tasted enough wine to accumulate wine knowledge and competences. In this era of 
social networks and massive visualization, a wine expert will be someone who shows that (s)he drinks a lot of wine, a lot of good wines and who is able to talk about them in a certain way that promotes her/him.

\subsection{Not to conclude: A vision of the future of corpus and semantics in digital humanities}

The statements made in the previous section raise a huge number of problems and challenges for linguists.

These considerations participate in a global movement of corpus thoughts aimed at rethinking the concept of corpus in the digital humanities (Garric \& Longhi, 2012, p. 5). The integration of sensorial and digital textuality compels linguists to re-invent corpus linguistics, corpus-concepts and corpus-constitutions.

We have seen supra that data is going to change with the integration of new information and new data, which stresses the need to rethink the conceptual framework.

It would also be interesting to improve the way corpora are built, stored, made accessible to the public and promoted to professionals like translators (cf. Loock, 2016b). Loock (2016a) underlies the needs of more ergonomics in corpus-software or web applications because, as is explained by Frérot (2010), translators do not use corpora since some specific knowledge is needed. Acquiring this knowledge takes time, which decreases the productivity of translators. Loock then offers to create Do-It-Yourself-Corpora which are unrefined, which means that there are not cleaned up, and free.

Let us return to the topic of sensorial speeches. If the problem of the selection of corpus data (especially the fuzziness of the demarcation line between expert and non-expert) is globally the same for digital and analogic corpora, the main interest will be foundaccording to us - in the variation between the intention of the speaker, what the speaker transmits and what the hearer receives. In this case, a combination of a both deductive and inductive approaches allows a global understanding of the conveyed and received meanings.

Thus, a speech act-analysis would be the first step in the analysis of the speaker's intention. To increase precision, it should be coupled with an ethnographic approach (Isani, 2014). A semantic propositions analysis (von Polenz, 2008) would provide answers to the 
question “'What has been said?' Finally, a cognitive semantic analysis like a frames-analysis (Ziem, 2008; Busse, 2012) would allow linguists to discover what has been understood by the receivers.

Such approaches would perfectly suit sensorial discourses, which are complex by nature.

\section{Notes}

1. The author thanks Candice Lemaire and Mitchell Katner for their thorough re-readings, and two anonymous referee for pointing out interesting elements on the first version of this paper.

2. Here it would make sense to like this to the Praha School and the work of Daneš (1974) on the thematic progression.

\section{Sensu Frame (2017).}

4. See the interesting study of de Grave (2007) about the Javanese senses comprehension.

5. The following assumptions made in this section are mostly built on research done in the wine language. These assumptions need of course to be verified and completed with research in other fields such as coffee, chocolate or food but also with music/sounds or painting.

6. The link between emotion and experience is clear and can obviously be found in the language, in the way one describes what has been eaten, seen or drunk (an example with coffee can be found in Bhumiratana et al., 2014).

7. For an introduction to the three first revolutions: Bach (2018, Part 1).

8. For an overview of the Internet era in the wine branch: Bach (2018, Part 3).

9. It must be underlined here that the massification of the digitalization of the production does not mean that human disappears of the process. We believe that this would be a reverse phenomenon in the sense that robots cannot find new customers or cannot work alone for a long time, they need a human help. Moreover, when they are confronted with systemic errors, they need to be helped by a human. That is why, we think that the work needed in a factory will evolve and become more complex, which will require more knowledge and skills from the employees.

10. A deeper explanation can be found in Schließmann, 2017.

11. The promotional video can be found here: https://www.youtube.com/watch?v=LqCVfn7mwgw.

12. We could object to this vision the fact that the future of automobile should be less oriented towards an owner-economy and more to a shared one, meaning that the equation "a driver has a car" will evolve to "one car has multiple drivers". The BMW future vision is however relatively realistic. 
13. For a hermeneutics approach: Balzer et al., 2018.

14. For a critical sight: Berra, 2012.

15. Or with the words of Wittgenstein: “denk nicht, sondern schau!” $(1953, \S 66)$.

16. A review is proposed by Teubert (2009).

17. Defined in Hoffmann 1985, Hutchinson \& Waters, 2010 and Lerat, 1995.

18. Strava is a social media platform used to share sport activities, which has the advantage to conglomerate activities from other native GPS platforms such as Suunto or Garmin.

19. We do not make a difference here between inter-, trans-, or multidisciplinary: the basic idea is to put different disciplines together and to make them enrich one another to reach specific goals. For the interested reader, we would prefer the term interdisciplinary in the way of Charaudeau (2010) (see Carlo, 2015).

20. Cance had developed for such notion the neologism "holisensorial" (2008, p. 383).

21. An interesting overview on the comparison of face-to-face- and computer-assisted-interaction has been made in Kafetsios et al., 2017.

22. On this notion about food blogs: Naulin, 2017, chap. 3 .

\section{Bibliography}

Andréys, C., Godin, K., and Wind, P. (2018). E-Commerce und Fachsprache am Beispiel des Weinhandels. In G. Schmale (Eds.), Néologie, Corpus, Méthodes d'analyse - Recherches en Langue de Spécialité (pp. 95-114). Saarbrücken: HTW Saar.

Ang, J. H., Goh, C., and Li, Y. (2016). Smart design for ships in a smart product through-life and industry 4.0 environment. 2016 IEEE Congress on Evolutionary Computation (CEC) (pp. 5301-5308). Vancouver.

Ascone, L., Dominguès, C., and Longhi, J. (2016). Perception de l'ambiance sonore d'un lieu selon sa représentation visuelle : une analyse de corpus. Corela, 14(1), http://corela.revues.org/4550. 
Auchlin, A., Filliettaz, L., Grobet, A., and Simon, A.-C. (2004). (En)action, expérienciation du discours et prosodie. Cahiers de linguistique française, 26, 217-249.

Baars, B. J. (2005). Global workspace theory of consciousness: toward a cognitive neuroscience of human experience? Progress in Brain Research, 150, 45-54.

Bach, M. (2017a). Prototypicité discursive dans les discours de vente du vin. Analyse contrastive français-allemand en Bourgogne et Rhénanie-Palatinat. Dijon: Université Bourgogne Franche-Comté.

Bach, M. (2017b). Metaphorische Anwendung von Hashtags im digitalen sozialen Netzwerk Instagram. GERALS - Zur Verwendung von Metaphern in Fachdiskursen des Deutschen, Lyon 27 oct. 2017. https://hal.archives-ouvertes.fr/hal-01625658.

Bach, M. (2018). Start-up du vin entre vrais apports et faux semblants. Paris: L'Harmattan.

Bach, M. (forthcoming). Das Textmuster in Online-Weinbeschreibungen: eine Hilfe für Übersetzer. Am Beispiel einer kontrastiven französisch-deutschen Analyse. In M. Schreiber, and S. Varga (Eds.), Fachsprachenforschung kontrastiv. Bern et al: Peter Lang.

Balzer, W., Eleftheriadis, A., and Kurzawe, D. (2018). Digital Humanities and Hermeneutics, Philosophical Inquiry, 42(3-4), 103-119.

Barbaresi, A. (2016). Collection and Indexation of Tweets with a Geographical Focus. In: Proceedings of the 4th Workshop on Challenges in the Management of Large Corpora (CMLC) (pp. 24-27). Portoroz.

Bauernhansl, T. (2017). Die Vierte Industrielle Revolution - Der Weg in ein wertschaffendes Produktionsparadigma. In B. Vogel-Heuser, T. Bauernhansl and M. ten Hompel (Eds.), Handbuch Industrie 4.0 Bd.4 (pp. 1-31). Berlin \& Heidelberg: Springer Vieweg.

Bernstein, R. (2010). The Pragmatic Turn. Cambridge \& Malden: Polity Press.

Berra, A. (2012). Faire des humanités numériques. In P. Mounier (Eds.), Read/Write Book 2 : Une introduction aux humanités numériques (pp. 25-43). Marseille: OpenEdition Press. http://books.openedition.org/oep/238. 
Berry, D. M. (2012). Introduction: Understanding the Digital Humanities. In D. M. Berry (Eds.), Understanding Digital Humanities (pp. 1-20). London: Palgrave Macmillan.

Bhumiratana, N., Adhikari, K., and Chambers, E. (2014). The development of an emotion lexicon for the coffee drinking experience. Food Research International, 61, 83-92.

Boutaud, Jean-Jacques (2007). Du sens, des sens. Sémiotique, marketing et communication en terrain sensible. Semen 23, https://journals.openedition.org/semen/5011.

Brühl, V. (2015). Industrie 4.0. In: V. Brühl (Eds.), Wirtschaft des 21. Jahrhunderts (pp. 61-107). Wiesbaden: Springer.

Bucher, H.-J. (2007). Textdesign und Multimodalität. Zur Semantik und Pragmatik medialer Gestaltungsformen. In K. S. Roth \& J. Spitzmüller (Eds.), Textdesign und Textwirkungen in der massenmedialen Kommunikation (pp. 49-76). Konstanz: Herbert von Halem.

Bucher, Hans-Jürgen (2010). Multimodalität - eine Universalie des Medienwandels: Problemstellungen und Theorien der Multimodalitätsforschung. In H.-J. Bucher \& T. Gloning \& K. Lehnen (Eds.), Neue Medien - Neue Formate. Ausdifferenzierung und Konvergenz in der Medienkommunikation (pp. 41-79). Frankfurt am Main: Campus.

Busse, D. (2012). Frame-Semantik, ein Kompendium. Berlin \& New York: de Gruyter.

Busse, D., and Teubert, W. (1994). Ist Diskurs ein sprachwissenschaftliches Objekt? In D. Busse \& F. Hermanns and W. Teubert (Eds.), Begriffsgeschichte und Diskursgeschichte. Methodenfragen und Forschungsergebnisse der historische Semantik (pp. 10-28). Opladen: Westdeutscher Verlag.

Cance, C. (2008). Expériences de la couleur, ressources linguistiques et processus discursifs dans la construction d'un espace visuel : l'habitacle automobile (Unpublished doctoral dissertation). Paris: Université Paris 3.

Candel, D. (2011). Linguistique appliquée : parcours définitoires et lexicographiques, Histoire Épistémologie Langage, 33(1), 99-115.

Carlo, C. (2015). "Pluri-inter-transdisciplinarité des recherches impliquées dans la description de la langue en usage. Comment penser la porosité des champs de recherche ? Recherches en didactique des langues et des cultures, 12(3), http://journals.openedition.org/rdlc/959. 
Charaudeau, P. (2010). Pour une interdisciplinarité «focalisée » dans les sciences humaines et sociales. Questions de Communication, 17, 195-222.

Charnock, R. (1999). Les langues de spécialité et le langage technique : considérations didactiques. ASp, 23-26, http://asp.revues.org/2566.

Condamines, A., and Narcy-Combes, J.-P. (2015). La linguistique appliquée comme science située. In F. Carton \& J.-P. Narcy-Combes, M.-F. Narcy-Combes and D. Toffoli (Eds.), Cultures de recherche en linguistique appliquée (pp. 209-229). Paris: Riveneuve éditions.

Damasio, A. (2018). The Strange Order of Things: Life, Feeling, and the Making of Cultures. New York: Pantheon Books.

Dang-Anh, M., Einspänner, J., and Thimm, C. (2013). Joint Digital Storytelling on Twitter: Creative Appropriation in Political Deliberation. AoIR, 14, https://spir.aoir.org/index.php/spir/article/view/842.

Daneš, F. (Ed.) (1974). Papers on Functional Sentence Perspective. Praha: Academia \& The Hague \& Paris: Mouton.

Daucé, B., and Rieunier, S. (2002). Le marketing sensoriel du point de vente, Recherche et Applications en Marketing, 17(4), 45-65.

Defossez, J., and Boutaud, J.-J. (2013). Communiquer sur le goût : du discours à la méthode, ESSACHESS Journal for Communication Studies, 6(11), 215-231.

Digonnet, R. (Eds.) (2018). Pour une linguistique sensorielle. Paris: Honoré Champion.

Dubois, D. (2009a). Avant-Propos. In D. Dubois (Eds.), Le sentir et le dire. Concepts et méthodes en psychologie et linguistique cognitives (pp. 7-8). Paris: L'Harmattan.

Dubois, D. (2009b). Le sentir et le dire : Définir l'objet et construire la démarche. In D. Dubois (Eds.), Le sentir et le dire. Concepts et méthodes en psychologie et linguistique cognitives (pp. 13-45). Paris: L'Harmattan.

Ekman, P. (2010). Gefühle lesen - Wie Sie Emotionen erkennen und richtig interpretieren. Trans: S. Kuhlmann-Krieg \& M. Reiss. Wiesbaden: Springer. 
Faber, P., \& África Vidal Claramonte, M. (2017). Food terminology as a system of cultural communication. Terminology, 23(1), 155-179.

Fairclough, N. (2005). Discourse analysis in organizational studies: the case for critical realism, Organization Studies, 26(6), 915-939.

Fairclough, N., \& Wodak, R. (1997). Critical Discourse Analysis. In T. van Dijk (Eds.), Discourse as Social Interaction (pp. 258-284). London: Sage.

Fen-Chong, J. (2017). Reconstruire et visualiser les pratiques touristiques dans l'Arc Jurassien à partir de la fouille semi-automatique de tweets [Research Project]. Dijon \& Besançon: Université Bourgogne Franche-Comté.

Fillmore, C. (1985). Frames and the Semantics of Understanding. Quaderni di Semantica, 6, 222-254.

Fillmore, C. (1992). "Corpus linguistics" or "Computer-aided armchair linguistics". In J. Svartvik (Eds.), Directions in corpus linguistics. Proceedings of Nobel Symposium 82, Stockholm 4-8 August 1991 (pp. 35-60). Berlin: Mouton de Gruyter.

Flichy, P. (2010). Le sacre de l'amateur. Sociologie des passions ordinaires à l'ère du numérique. Paris: Le Seuil.

Flutet, G. (2015). Délimitation des AOC : la matérialisation des limites géographiques du lien au terroir d'une production. In S. Wolikow \& F. Humbert (Eds.), Une histoire des vins et des produits d'AOC. L'INAO, de 1935 à nos jours (pp. 191-197). Dijon : Éditions universitaires de Dijon.

Frame, A. (2017). What Future for the Concept of Culture in the Social Sciences? Epistémè, 17, $151-172$.

Frérot, C. (2010). Outils d'aide à la traduction : pour une intégration des corpus et des outils d'analyse de corpus et dans l'enseignement de la traduction et la formation des traducteurs. Les Cahiers du GEPE 2, www.cahiersdugepe.fr/index.php?id=1164.

Gardner, H. (1985). The Mind's New Science: A History of the Cognitive Revolution. New York: Basic Books. 
Gautier, L. (2014). Des langues de spécialité à la communication spécialisée: un nouveau paradigme de recherche à l'intersection entre sciences du langage, info-com et sciences cognitives ? Études Interdisciplinaires en Sciences humaines, Collège Doctoral Francophone Régional d'Europe Centrale et Orientale en Sciences Humaines (CODFREURCOR), 225-245.

Gautier, L. (Eds.) (2017). Figement et discours spécialisés. Berlin: Frank \& Timme.

Gautier, L. (2018). Émotions, expressivité et évaluation. La triple face (cachée ?) des descripteurs sensoriels : l'exemple du discours de présentation/dégustation de vins. Symposium Connaître vs. ressentir. Affects, émotions et expressivité en discours spécialisés, Lyon 2, March 2018. https://halshs.archives-ouvertes.fr/halshs-01722225.

Gautier, L., and Bach, M. (2017). La terminologie du vin au prisme. Des corpus oraux de dégustation / présentation (français-allemand) : Entre émotions, culture et sensorialité. Études de Linguistique Appliquée, 188, 485-509.

Gautier, L., and Bach, M. (2019). Von Patterns zu fachspezifischen Konstruktionen im Fachdiskurs Eine kontrastive Fallstudie (deutschfranzösisch) zu Weinsprache. Europhras 2019 Productive patterns in phraseology, Santiago de Compostela, 24-25. Jan. 2019.

Garric, N., and Longhi, J. (2012). L'analyse de corpus face à l'hétérogénéité des données : d'une difficulté méthodologique à une nécessité épistémologique. Langages, 187(3), 3-11.

Geeraerts, D. (2006). Words and Other Wonders. Berlin \& New York: Mouton de Gruyter.

Gilquin, Gaëtanelle (2010). Corpus, Cognition and Causative Constructions. Amsterdam \& Philadelphia: John Benjamins.

Goldberg, A. (1995). Constructions. A Construction Grammar Approach to Argument Structure. Chicago et al.: University of Chicago Press.

Goldberg, A. (2006). Constructions at Work. The Nature of Generalization in Language. Oxford: Oxford University Press.

Goldstein, P., Weissman-Fogel, I., Dumas, G., and Shamay-Tsoory, S. G. (2018). Brain-to-brain coupling during handholding is associated with pain reduction. Proceedings of the National Academy of Sciences, 115(11), 28-37.

Gordon, B. (1986). The Souvenir: Messenger of the Extraordinary. The Journal of Popular Culture, 20(3), 135-146. 
de Grave, J.-M. (2007). Quand ressentir c'est toucher. Techniques javanaises d'apprentissage sensoriel. Terrain, 49, 77-88.

Gréciano, G. (1995). Fachphraseologie. In R. Métrich \& M. Vuillaume (Eds.), Band und Rand. Abgrenzung und Verknüpfung als Grundtendenzen des Deutschen (pp. 183-195). Tübingen: Narr.

Gries, S. T., \& Slocum, B. G. (2017). Ordinary Meaning and Corpus Linguistics. BYU Law Review, 6, $1417-1472$.

Guastavino, C. (2009). Validité écologique des dispositifs expérimentaux. Pour qui ? Pour quoi ? Pour quoi faire? In: D. Dubois (Eds.), Le sentir et le dire. Concepts et méthodes en psychologie et linguistique cognitives (pp. 233-252). Paris: L'Harmattan.

He, S., Zheng, X., Zeng, D., Luo, C., and Zhang, Z. (2016). Exploring Entrainment Patterns of Human Emotion in Social Media. PloS one, 11(3), e0150630.

Heiden, S. (2010). The TXM Platform: Building Open-Source Textual Analysis Software Compatible with the TEI Encoding Scheme. In R. Otoguro and K. Ishikawa and H. Umemoto and K. Yoshimoto and Y. Harada (Eds.), 24th Pacific Asia Conference on Language, Information and Computation (pp. 389-398). Institute for Digital Enhancement of Cognitive Development, Waseda University.

Hoffmann, L. ( $\left.{ }^{2} 1985\right)$. Kommunikationsmittel Fachsprache. Eine Einführung. Tübingen: Narr.

Hutchinson, T., and Waters, A. ([1987] $\left.{ }^{25} 2010\right)$. English for Specific Purposes. A learning-centred approach. Cambridge et al:: Cambridge University Press.

Instagram: Platform Policy. Instagram, https://www.instagram.com/developer/.

Isani, S. (2014). Ethnography as a research-support discipline in ESP teaching, learning and research in the French academic context. ASp, 66, http://asp.revues.org/4531.

Jacobs, M., and Spillman, L. (2005). Cultural sociology at the crossroads of the discipline. Poetics, $33(1), 1-14$. 
Kafetsios, K., Chatzakou, D., Tsigilis, N., and Vakali A. (2017). Experience of emotion in face to face and computer-mediated social interactions: An event sampling study. Computers in Human Behavior, 76, 287-293.

Kolberg, D., and Zühlke, D. (2015). Lean Automation enabled by Industry 4.0 Technologies, IFACPapersOnLine, 48(3), 1870-1875.

Kress, G., and Leuwen, T. v. (2001). Multimodal Discourse. The Modes and Media of Contemporary Communication. London: Arnold.

Lakoff, G. (1987). Women, Fire, and Dangerous Things. What categories reveal about the mind. Chicago \& London: The University of Chicago Press.

Lamarre, G. (2018). L'art du storytelling. Manuel de communication. Paris: Pyramid.

Ledoux, J. E., and Hofmann, S. G. (2018). The subjective experience of emotion: a fearful view. Current Opinion in Behavioral Sciences, 19, 67-72.

Leech, G. (1992). Corpora and theories of linguistic performance. In J. Svartvik (Eds.), Directions in Corpus Linguistics (pp. 105-122). Berlin: Mouton de Gruyter.

Lemnitzer, L., and Zinsmeister, H. (32015). Korpuslinguistik. Eine Einführung. Tübingen: Narr.

Lerat, P. (1995). Les langues spécialisées. Paris: PUF.

Longhi, J. (2009). Les objets discursifs et le phénomène d'anticipation lexicale du discours : processus de référenciation et argumentativité dans l'activité discursive. In N. Garric \& J. Longhi (Eds.), L'analyse linguistique des corpus discursifs. Des théories aux pratiques, des pratiques aux théories (pp. 69-92). Clermont-Ferrand : Presses Universitaires Blaise-Pascal.

Longhi, J. (2016). Le tweet politique efficace comme mème textuel : du profilage à viralité. Travaux de linguistique, 73, 107-126.

Longhi, J. (2018). L'écriture nativement numérique, de Twitter à Youtube : pour une approche nonconversionnelle des processus créatifs, Le français aujourd'hui, 200, 43-54. 
Longhi, J., Marinica, C., Hassine, N., Alkhouli, A., and Borzic, B. (2017). The \#Idéo2017 Platform. In E. W. Stemle and C. R. Wigham (Eds.), Proceedings of the 5th Conference on CMC and Social Media Corpora for the Humanities (cmccorpora17) 3-4 October 2017, Eurac Research, Italy, 46-51.

Loock, R. (2016a). L'utilisation des corpus électroniques chez le traducteur professionnel : quand ? comment ? pour quoi faire ? ILCEA, 27, http://journals.openedition.org/ilcea/3835.

Loock, R. (2016b). La Traductologie de corpus. Lille: Presses Universitaires du Septentrion.

Majid, A., and Burenhult, N. (2014). Odors are expressible in language, as long as you speak the right language. Cognition, 130, 266-270.

McKenna, K. Y.A., and Bargh, J. A. (1999). Causes and Consequences of Social Interaction on the Internet: A Conceptual Framework. Media Psychology, 1(3), 249-269.

Mindas, M., and Bednar, S. (2016). Mass customization in the context of industry 4.0: implications of variety-induced complexity. In D. Plinta (Eds.), Advanced industrial engineering: Industry 4.0 (pp. 21-39). Bielsko-Biała: Wydawnictwo Fundacji Centrum Nowych Technologii.

Merleau-Ponty, M. (1969). La prose du monde. Paris: Gallimard.

Mitchell, W.J.T. (1994). Picture Theory: Essays on Verbal and Visual Representation. Chicago: The University of Chicago Press.

Mondada, L. (2018). The multimodal interactional organization of tasting: Practices of tasting cheese in gourmet shops. Discourse Studies, 1-27, https://doi.org/10.1177/1461445618793439.

Mondada, L., \& Dubois, D. (1995). Construction des objets de discours et catégorisation : une approche des processus de référenciation, TRANEL, 23, 273-302.

Morange, S. (2009). Expert? Vous avez dit expert? In D. Dubois (Eds.), Le sentir et le dire. Concepts et méthodes en psychologie et linguistique cognitives (pp. 137-156). Paris: L’Harmattan.

Mukherjee, J. (2010). Corpus linguistics versus corpus dogmatism - pace Wolfgang Teubert. International Journal of Corpus Linguistics, 15(3), 370-378. 
Naulin, S. (2017). Des mots à la bouche. Le journalisme gastronomique en France. Tours: Presses Universitaires François-Rabelais de Tours \& Rennes: Presses Universitaires de Rennes.

Paveau, M.-A. (2013a). Genre de discours et technologie discursive. Tweet, twittécriture et twittérature. Pratiques 157-158, 7-29.

Paveau, M.-A. (2013b). Technodiscursivités natives sur Twitter. Une écologie du discours numérique. Epistémé, 9, 139-176.

Petit, M. (2005). La notion de style spécialisé et les divers types de 'spécialisé'. In Z. Hokrova et al. (Eds.), Sborník Príspevku Z Konference PROFILINGUA 2005 (Actes de la Conférence Profilingua 2005) (pp. 140-144). Pilsen: Zapadoceska univerzita v Plzni.

Popper, K. R. (1999). La connaissance objective. Paris: Flammarion.

Resche-Rigon, P. (2009). Dire ou vouloir dire. Du langage idéal au bricolage des langues. In D. Dubois (Eds.), Le sentir et le dire. Concepts et méthodes en psychologie et linguistique cognitives (pp. 47-74). Paris: L'Harmattan

Richins, M. L. (1997). Measuring Emotions in the Consumption Experience. Journal of Consumer Research, 24(2), 127-146.

Ricœur, P. (2006). Mémoire, Histoire, Oubli. Esprit 3, 20-29.

Rorty, R. (Eds.) (1967). The Linguistic Turn: Recent Essays in Philosophical Method. Chicago \& London: The University of Chicago Press.

Rosch, E. (1973). Natural Categories. Cognitive Psychology, 4(3), 328-350.

Rosch, E. (1975). Cognitive Reference Points. Cognitive Psychology, 7(4), 532-547.

Römer, U. (2008). Identification impossible? A corpus approach to realisations of evaluative meaning in academic writing. Functions of Language, 15(1), 115-130.

San Roque, L., Kendrick, K. H., Norcliffe, E., and Majid, A. (2018). Universal meaning extensions of perception verbs are grounded in interaction. Cognitive Linguistics, 29(3), 371-406 
Schlick, J., Stephan, P., Zühlke, D., and DFKI (2013): Produktion 2020: Auf dem Weg zur 4. industriellen Revolution. In A.-W. Scheer (Eds.), Industrie 4.0 - Wie sehen Produktionsprozesse im Jahr 2020 aus? (pp. 12-21). Saarbrücken: IMC AG.

Schließmann, A. (2017). iProduction, die Mensch-Maschine-Kommunikation in der Smart Factory. In B. Vogel-Heuser \& T. Bauernhansl and M. ten Hompel (Eds.), Handbuch Industrie 4.0 Bd.4 (pp. 173202). Berlin \& Heidelberg: Springer Vieweg.

Schriver, K. A. (1997). Dynamics in Document Design: Creating text for readers. New York \& Chichester: Wiley.

Schwarz-Friesel, M. (2013). Sprache und Emotion. Tübingen \& Basel: Francke.

Sfar, I. (2013): Les collocations dans le discours spécialisés : le cas de la terminologie ornithologique. Language Design, 14, 19-38.

Sharifian, F. (2017). Cultural Linguistics. Amsterdam \& Philadelphia: John Benjamins.

Spina, S. (2017). Emoticons as multifunctional and pragmatic Resources: a corpus-based Study on Twitter. In E. W., Stemle and C. R., Wigham (Eds.), Proceedings of the 5th Conference on CMC and Social Media Corpora for the Humanities (cmccorpora17) 3-4 October 2017, (pp. 25-30). Eurac Research, Italy.

Stenger, T. (2004). L'interactivité dans la relation d'achat en ligne: entre information et prescription? Le cas de la vente de vin par Internet (Unpublished doctoral dissertation). Poitiers: Université de Poitiers.

Svartvik, J. (2007). Corpus linguistics 25+ years on. In R. Facchinetti (Eds.), Corpus Linguistics 25 Years on (pp. 11-26). Amsterdam \& New York: Rodopi.

Svenson, P. (2010). The Landscape of Digital Humanities. Digital Humanities, 4(1), http://digitalhumanities.org/dhq/vol/4/1/000080/000080.html.

Teubert, W. (2005). My version of corpus linguistics. International Journal of Corpus Linguistics, 10(1), 1-13. 
Teubert, W. (2009). Corpus Linguistics: An Alternative. Semen, 27, http://journals.openedition.org/semen/8912.

Thimm, C., Dang-Anh, M., and Einspänner, J. (2011). Diskurssystem Twitter: Semiotische und handlungstheoretische Perspektiven. In M. Anastasiadis (Eds.), Social Media- Theorie und Praxis digitaler Sozialität (pp. 265-286). Frankfurt am Main: Peter Lang.

Thimm, C., Anastasiadis, M., and Einspänner-Pflock, J. (2017). Deliberation im Netz - Formen und Funktionen des digitalen Diskurses am Beispiel des Microbloggingsystems Twitter. In F. Krotz \& C. Despotović \& M.-M. Kruse (Eds.), Mediatisierung als Metaprozess. Transformationen, Formen der Entwicklung und die Generierung von Neuem (pp. 259-280). Wiesbaden: Springer.

Thimm, C., and Nehls, P. (2017). Sharing grief and mourning on Instagram: Digital patterns of family memories. Communications, 42(3), 327-349.

Tognini-Bonelli, E. (2001). Corpus Linguistics at Work. Amsterdam \& Philadelphia: Benjamins.

Valentin, D., Chollet, S., and Abdi, H. (2003). Les mots du vin : experts et novices diffèrent-ils quand ils décrivent des vins ? Corpus, 2, http://journals.openedition.org/corpus/36.

Vandeloise, C. (1991). Spatial prepositions: A case study from French. Chicago: University of Chicago Press.

Vernet, F., and Rieunier, S. (2004). Le marketing sensoriel chez Nature \& Découvertes: 10 ans d'évolution de l'offre sensorielle en restant à l'écoute du consommateur. Décisions du Marketing, 33, 77-80.

von Polenz, P. (2008). Deutsche Satzsemantik. Berlin \& New York: de Gruyter.

Wagener, A. (2016). Prédiscours, interdiscours et postdiscours : analyse critique de la circulation des possibles discursifs. Revue de Sémantique et Pragmatique, 39, 95-110.

Wang, Y., and Ma, H.-S., and Yang, J.-H., and Wang, K.-S. (2017). Industry 4.0: a way from mass customization to mass personalization production. Advances in Manufacturing, 5(4), 311-320.

Wittgenstein, L. ([1953] ${ }^{8}$ 2017): Philosophische Untersuchungen. Frankfurt am Main: Suhrkamp Verlag. 
$\mathrm{Xu}$, A., and Liu, Z., and Guo, Y., and Sinha, V., and Akkiraju, R. (2017). A New Chatbot for Customer Service on Social Media. CHI '17 Proceedings of the 2017 CHI Conference on Human Factors in Computing Systems, 3506-3510.

Ziem, A. (2008). Frames und sprachliches Wissen: Kognitive Aspekte der semantischen Kompetenz. Berlin \& New York: de Gruyter.

\section{Address for correspondence}

\section{Matthieu BACH}

Université Bourgogne Franche-Comté (EA4182)

matthieubach.pro@gmail.com 